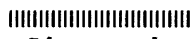

論文

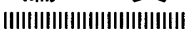

\title{
コイル材切削法による金属繊維製造装置の開発
}

$\begin{array}{llllll}\text { 日本工業大学 } & \text { 兼 } & \text { 子 } & \text { 正 } & \text { 生（会員） } \\ \text { 日本工業大学 } & \text { 柳 } & \text { 沢 } & \text { 章 } \\ \text { 日本工業大学 } & \text { 鈴 } & \text { 木 } & \text { 烹 }\end{array}$

\section{Development of Metal Fiber Production Equipments by Using Coiled Sheet Shaving Method}

\author{
Masao Kaneko, Akira Yanagisawa and Tohru Suzuki \\ Nippon Institute of Technology, \\ Gakuendai Miyashiro-cho Minamisaitama-gun Saitama
}

\begin{abstract}
This investigation was conducted to put to practical application coiled sheet shaving method. To prevent the fiber from sticking to each other during shaving, a new method using hot water soluble resin coated coil was proposed. Production equipments for the new method which can be applied industrially were developed and their basic performances were examined. It was confirmed that fiber sticking could be prevented with coating thickness of $12 \sim 20 \mu \mathrm{m}$ and various kinds of metal fibers as stainless steel, nickel, titanium could be produced efficiently by the developed equipments Further, non-woven fabric production equipments was developed suitable for these fibers eliminating problems such as breaking of fibers with the current non-woven fabric production methods.
\end{abstract}

(Received November 24, 1995)

(Accepted for Publication May 14, 1996)

摘 要

目的 優れた特徴の多いコイル材切削法による金属繊維の製造法を実用化することを目的として，製法上の問題点を解消す る方法と, それの対応する製造装置の検討を行った。

成果 製法上の問題点である, 切削時の薄板相互の溶着防止効果に優れた分離膜材として湯溶性樹脂であるポリビニルアル コール（PVAL）を用い,コイル素材への被覆装置, 㵶維製造装置を開発した.これらの装置を用い各種ステンレス鋼, ニッケ

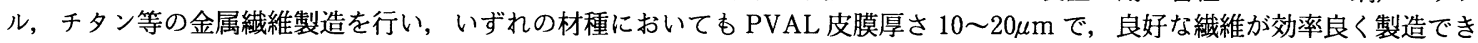
た．また，コイル材切削法のような切削で得られる折損しやすい金属瀻維に適した不織布製造装置を開発した。

(平成 7 年11月 24 日受理) (平成 8 年 5 月 14 日審查終了)

\section{1. 緒 言}

金属繊維は耐熱性，焼結性，電気伝導性等の非金 属繊維にはない優れた特性を持っている．金属繊維 は鉛やアルミニウム合金, $\mathrm{Fe}-\mathrm{B}-\mathrm{Si}$ 系アモルファス 緘維等を除いて溶融紡糸法によって製造されてい る. 現在，金属繊維を工業的に製造する方法として
は, 単線引抜き法, 集束引抜き法 ${ }^{1)}$ の引抜き法と, ワ イヤ切削法 ${ }^{2)}$, びびり振動切削法 ${ }^{3)}$ の切削法が行われ ている. 引抜き法は一般に高品質の繊維製造法であ るが，非常に高コストであり，中でも細径の織維の 得られる集束引抜き法はオーステナイト系ステンレ ス鋼繊維以外は製造しにくいという欠点を持ってい る. 一方，ワイヤ切削法はコスト的には優れている 
あのの, 均一な径の繊維製造が困難であり, 被削性 の劣る材種には適用できない等の問題がある。ま た,びびり振動切削法は短繊維の製造法であり, 長 繊維の製造は困難である。

筆者らはこれまで, 多材種に適応でき, 繊維径の 設定が容易かつ正確に行える，製造装置が簡便で低 コストの繊維製造法である等の優れた特徴を持つ,

コイル材切削法による金属繊維製造の研究を行って きた。 その結果，金属薄板をコイル状に巻き，その 端面を切削し金属瀻維を得るコイル材切削法におい て, 実用化を妨げている最大の問題点とされていた 切削時の薄板相互の溶着を防止する方法を開発し た ${ }^{4,5)}$, この方法はコイル素材に溶着防止のための除 去の容易な分離膜を被覆して切削し, 後にその分離 膜を洗浄除去する湯溶性樹脂被覆コイル材切削法で ある。

本報告では, この新しく開発した湯溶性樹脂被覆 コイル材切削法の工業的実用化を目指し，樹脂被覆 装置, 緎維製造装置の開発を行い, その基本的性能 について検討を行った.

さらに，金属繊維は多くの用途において，これを 不織布として用いることが多い。これらは, 自動車 用マフラーの消音材, また, 焼結体としてポリマー フィルター等の各種フィルター, 面燃焼バーナーの 他多孔質素材として広く用いられている。しかし， 金属繊維不織布の製造においては, カード式, ラン ダムウェブ方式等の非金属瀻維における従来の方法 がそのまま用いられているため, 繊維折損などの問 題点も生じている．特に, コイル材切削法金属繊維 のような折損しやすい金属瀻維を上記用途に適用し ようとする場合，これに適した不織布製造法の開発 が必要となる.

本研究ではコイル材切削法で製造された金属繊維 が実用に供されるために，これを不織布とするため の製造装置の開発も行った。

\section{2. 金属繊維製造装置}

\section{1 湯溶性樹脂被覆コイル材切削法}

コイル材切削法を図 1 に示す。この方法では, コ イル材の板厚と工具の送り量を変えることで任意で しかむ均一な太さの繊維が得られる，また，旋削加 工であることから切削可能な多材種への適応が可能 であり, 現在, 行われている集束伸線法, ワイヤシ エービング法等の他の方法に比較して製造装置が簡

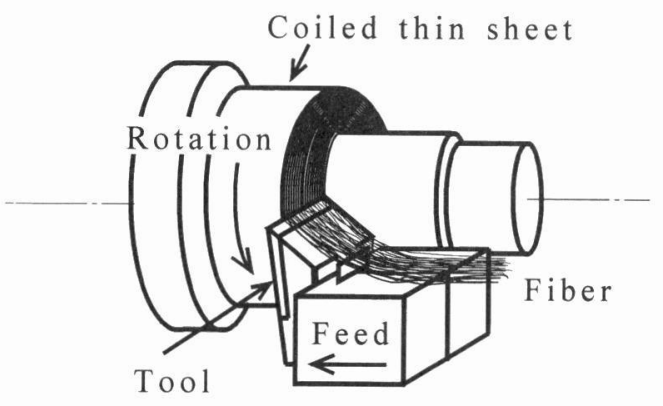

Fig. 1 Schematic illustration of the coiled sheet shaving method

便となり，繊維製造法として，多くの利点を持って いる。しかしながら，この方法で繊維の製造を行う と, 図 2 (a) に示すょうに, 多くの材質において, 切削時に薄板相互が溶着し, 帯状の切りくずとなり 繊維としての形態が得られない. 繊維溶着は薄板相 互の金属接合現象 ${ }^{4}$ であり，薄板層間に樹脂等の分 離膜材を形成させ切削することが溶着防止に有効で あることが確認されている5 して湯溶性樹脂を用いる方法が湯溶性樹脂被覆コイ ル材切削法である.ここで, 分離膜材として湯溶性

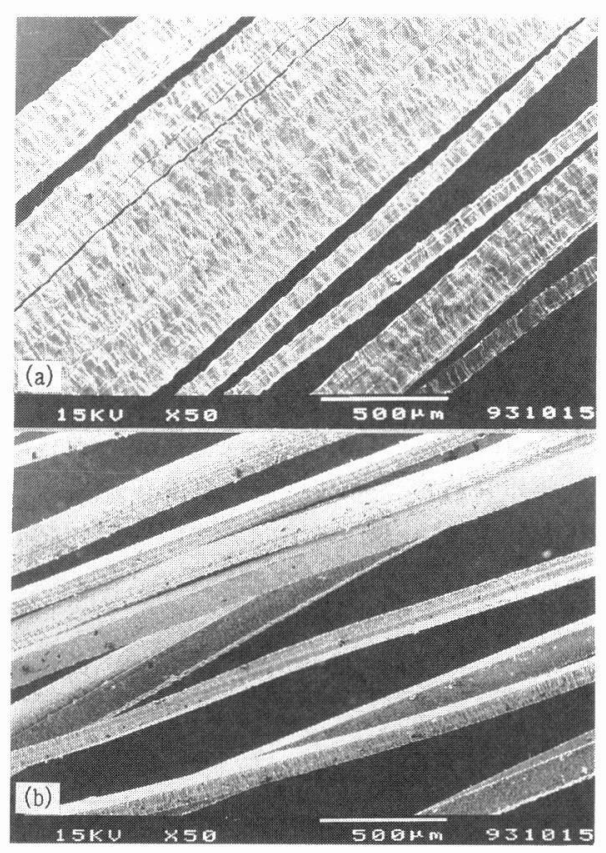

SUS304, $\mathrm{t}=0.1 \mathrm{~mm}, \quad \mathrm{~V}=80 \mathrm{~m} / \mathrm{min}, \quad \mathrm{S}=20 \mu \mathrm{m} / \mathrm{rev}, \quad \gamma=25^{\circ}$

Fig. 2 Comparison of appearances of fibers produced by non-coated sheet shaving (a) and coated sheet shaving (b) 


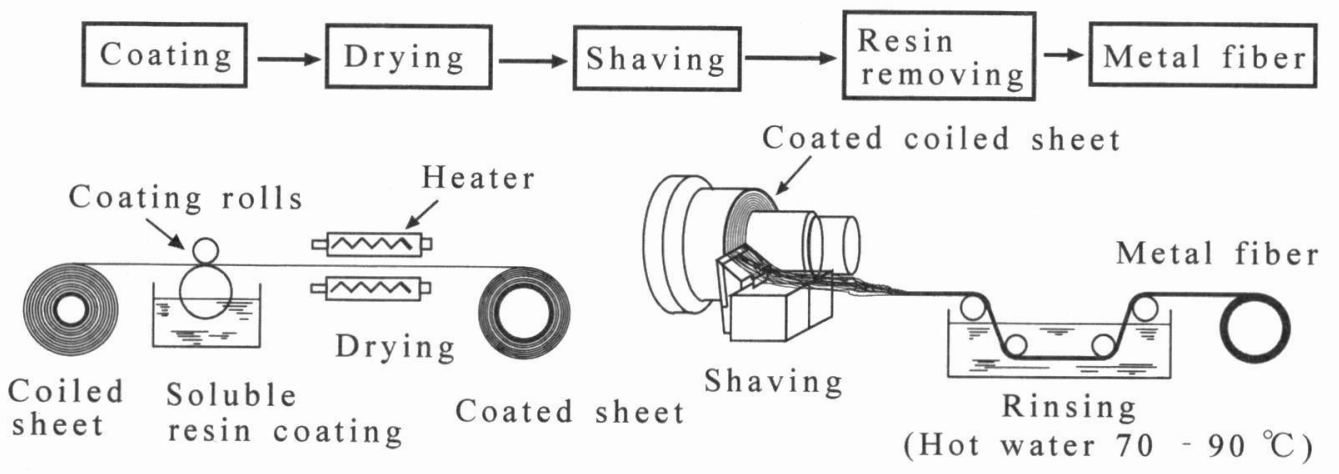

Fig. 3 Hot water soluble resin coating and resin removing process

樹脂を用いる理由は次の通りである，ステンレス鋼 織維の製造には切削油剤を使用することが不可欠で あるが, 不水溶性切削油剂を用いると繊維に付着し た油剤の除去が困難となることから，除去の容易な 水溶性切削油剤が用いられる必要がある. 従って, 分離膜材に要求される特性として, 切削油剂には溶 解せず, 切削中分離膜材としての性能が維持され, かつ, 繊維製造後, 容易に除去処理が可能であるこ とがあげられる.これらの要求を満たす分離膜材を 検討した結果, 水溶性切削油剤には溶解せず $65^{\circ} \mathrm{C}$ 以 上の温水にのみ溶解する湯溶性樹脂であるケン化度 $88 \pm 1 \mathrm{~mol} \%$ のポリビニルアルコール（以下 PVAL と呼ぶ）が選択された. 湯溶性樹脂被覆コイル材切 削法の繊維製造工程を図 3 に示す。また, 表 1 に本 法で用いた PVAL の物性值を示す. 工程は, まずコ イル素材に湯溶性樹脂が被覆され, 乾燥後, 巻き取 られて被覆コイル材となる。この被覆コイル材は切 削装置の主軸に所定量巻き取られ，その端面が切削 され金属繊維が得られる. 得られた金属纎維は温水 により緘維に残存する被覆樹脂が洗浄除去された 後, 巻き取られる. 図 2 (b) に, この方法で製造さ れた溶着のない金属䋐維の外観を示す.

Table 1 Physical properties of PVAL

\begin{tabular}{l|l}
\hline \hline Chemical formula & $-\left(\mathrm{CH}_{2}-\mathrm{CH}\right)_{n}-$ \\
\hline Decomposition point & \multicolumn{1}{c}{$\mathrm{OH}^{-}$} \\
\hline Me1ting point & $200 \sim 220^{\circ} \mathrm{C}$ \\
\hline Dissolution temperature & $>65{ }^{\circ} \mathrm{C}$ \\
\hline Viscosity & $25 \pm 2 \mathrm{CPS} / 4 \% 200^{\circ} \mathrm{C}$ \\
\hline Saponification & $88 \pm 1 \mathrm{mo} \%$ \\
\hline pH & $5.5 \sim 6.5$ \\
\hline
\end{tabular}

\section{2 樹脂被覆装置}

開発した樹脂被覆装置を図 4 に示す。この装置に より，金属薄板はコーティングロールで樹脂が塗布 され，輻射伝熱あるいは熱風対流により乾燥された 後, 専用ドラムに巻き取られる.この専用ドラムに 巻き取られた被覆素材は, 次工程の切削装置の素材 ドラム装着部に取り付けられる.コーティングロー ル部の詳細を図 5 に示す. PVAL の塗布量を一定に するために供給ロールと転写ロールを用い, 供給口 ールにドクタブレードが取り付けられ樹脂量の調整 が行われる. 常温の PVAL10\%水溶液を用い,ドク タブレードと供給ロールとクリアランス C, コーテ ィングロール周速度 $V c$, 薄板材の巻取速度 $V w$ を 変えた場合の PVAL の被覆厚さの变化を図 6 に示 す. PVAL 被覆厚さは SUS304, SUS430, チタン, ニッケル等の材種による差異は認められず, 各巻取 速度に応じ, クリアランス, コーティングロール速 度を変えることにより $5 \sim 30 \mu \mathrm{m}$ の任意の厚さに塗 布できることが確認できた。

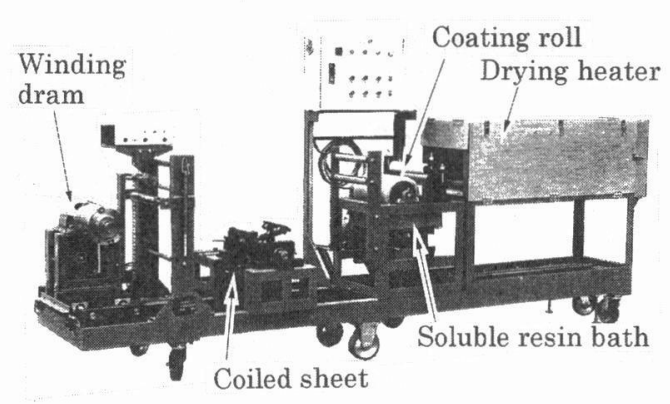

Fig. 4 Resin coating machine 


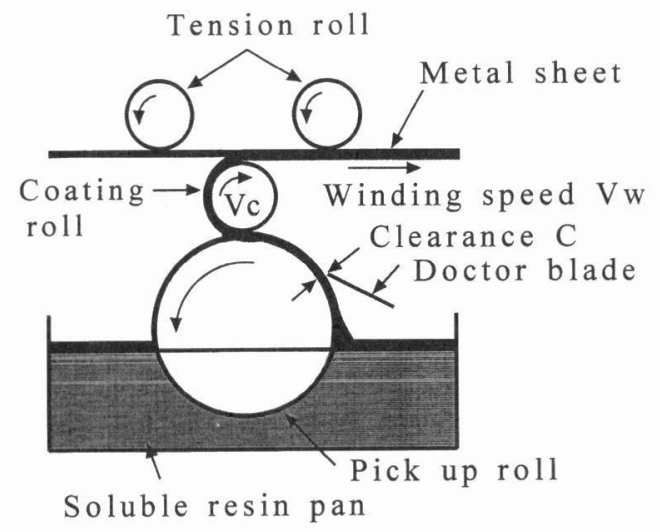

Fig. 5 Coating equipment of hot water soluble resin

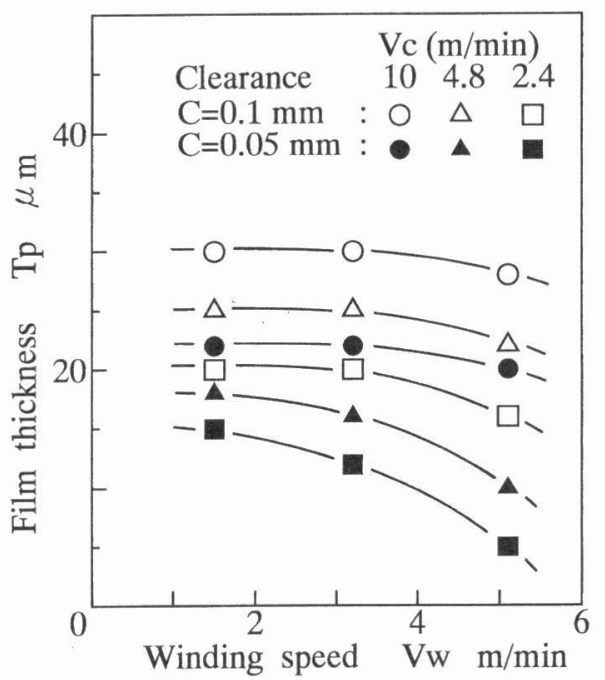

Fig. 6 Relation between coating roll speed, winding speed and coated film thickness

\section{3 緎維製造装置}

コイル材切削法は旋削であることから, 繊維製造 装置は基本的に施盤と同様の構造を持っている．ま た, 得られる絆維は薄板の切削であることから長方 形断面となる。このような円以外の断面を持つ繊維 の場合，通常これを同じ面積の円に換算したときの 直径を換算直径として表す．この換算直径 $20 \sim 60$ $\mu \mathrm{m}$ の金属繊維を製造するためには，板厚 $0.05 \sim$ $0.1 \mathrm{~mm}$ のコイル材を用いても, 切削 1 回転当たり の工具送り量を $10 \sim 20 \mu \mathrm{m} / \mathrm{rev}$ の微小量としなけ ればならない。この微小送り量で単位時間当たりの

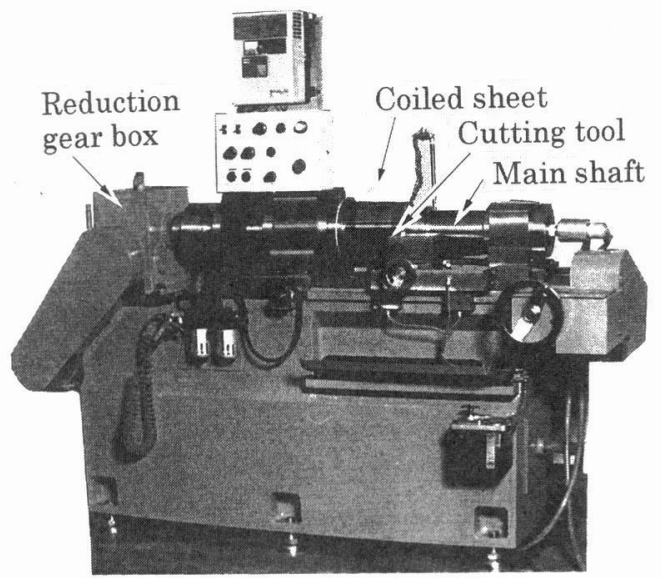

Fig. 7 Coiled sheet shaving machine

生産量を確保するためには, 切削幅を大きくするこ とが必要となる，微小送り，大きな切削幅の切削条 件はびびり振動を非常に生じやすく, びびり振動が 生じると繊維が切断され, 連続的な生成は行われな くなる．このびびり振動の発生を防止するため, 製 造装置には高剛性, バックラッシュのない主軸回 転, 安定した微小送りが必要となる。これらの要求 を満たすために, 専用の繊維製造装置の製作を行っ た。図 7 に試作した製造装置の外観を示す。

初めに, 回転の変動が少なく安定した主軸回転を 得るために, 衝撃荷重に耐え, バックラッシュの調 整が可能な特殊減速機（1：10.25）をカップリング により主軸に直接接続し, バックラッシュの起こり にくい機構とした。 また， $5 \sim 30 \mu \mathrm{m} / \mathrm{rev}$ 以下の安 定した工具送りを得るため, ピッチ $5 \mathrm{~mm}$ のボー ルねじをべッドの中央に設置した。 さらに，微小送 り量を実現するために，送り減速機にハーモニック ドライブ（1/50）を採用，インバーターにより 5 $50 \mu \mathrm{m} / \mathrm{rev}$ の安定した送り量の得られる機構とし た.

この試作した製造装置を用い,びびり振動が発生 せず，連続繊維の生成する切削条件の検討を行っ た. 板厚 $t=0.03,0.05,0.1 \mathrm{~mm} の$ SUS304 材を用 いた場合の結果を図 8 に示す．繊維生成域は SUS 304, SUS430, ニッケル, チタン材で, ほぼ同様の 傾向を示し, 送り量が減少するとそれに伴って, 連 続繊維の生成可能な切削幅が小さくなる.これは送 り量が減少することにより, 生成瀻維がより細径と なるため, わずかなびびり振動の発生でも繊維切断 が生じやすくなるためと, 切れ刃先端の丸み半径 


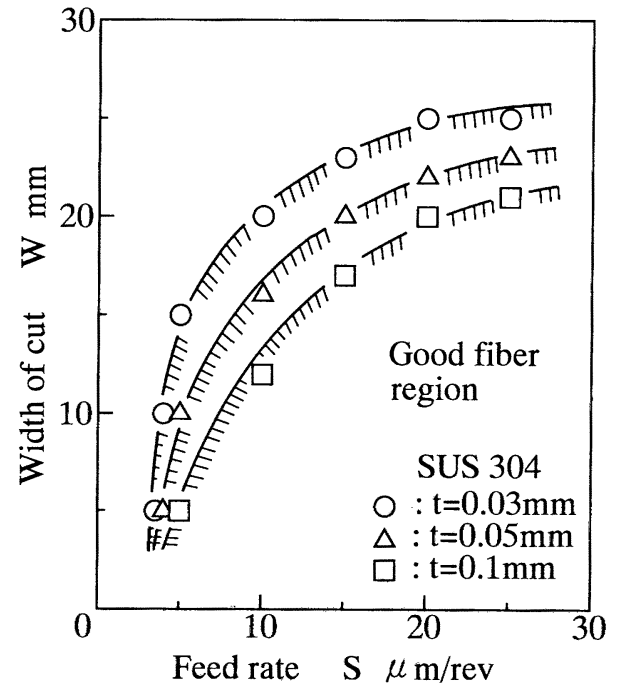

Fig. 8 Fiber formation region

(工具研削直後の切れ刃先端の平均丸み半径 $R=$ $20 \mu \mathrm{m}$ ) が切削厚さ（送り量に相当）に対して相対的 に大きくなり，連続型切りくずである繊維の生成が 困難になるためと考えられる.

さらに，織維製造装置の主軸に被覆コイル材を巻 き取る場合, コイル材の巻取張力が小さいと緊密な 巻き付け状態が得られず, 切削中にコイル材層間で の変形, 外周部でのめくれが発生し, 連続した繊維 の製造が困難となった．この問題を回避するために 製造装置の素材ドラム部にブレーキ装置を取り付 け，緊密な巻き付け状態が得られるようにした．板 厚 $t=0.1 \mathrm{~mm}$, 板幅 $200 \mathrm{~mm}$ の場合には $120 \sim 150$ $\mathrm{N} \cdot \mathrm{m}$, 板厚 $t=0.03 \mathrm{~mm}$ の場合には $100 \sim 130 \mathrm{~N}$ ・ $\mathrm{m}$ のブレーキトルクで良好な巻き付け状態が得ら れた.

次に, 溶着防止可能な PVAL 被膜厚さについて 検討した. 図 9 KUS304, 板厚 $t=0.1 \mathrm{~mm}$ を用い た場合の PVAL 被膜厚さと溶着率の関係を示す。 ここで, 繊維溶着率とは本来生成されるべき織維本 数（コイル材の巻数に相当）を $N$, 実際に分離生成 される繊維本数（目視により測定）を $\mathrm{n}$ とする $\{(N-n) / N\} \times 100(\%)$ で表され, 切削時の生成 緘維相互の溶着の程度を示している. 被膜厚さが $3 \mu \mathrm{m}$ では溶着防止効果が不十分で, 被覆を行わな い場合に比べ, 溶着率の低減は 10\%程度であった。 皮膜厚さ $5 \mu \mathrm{m}$ とすると溶着率は急激に減少し被膜 厚さ $10 \mu \mathrm{m}$ 以上では溶着率は $10 \%$ 以下にまで低下

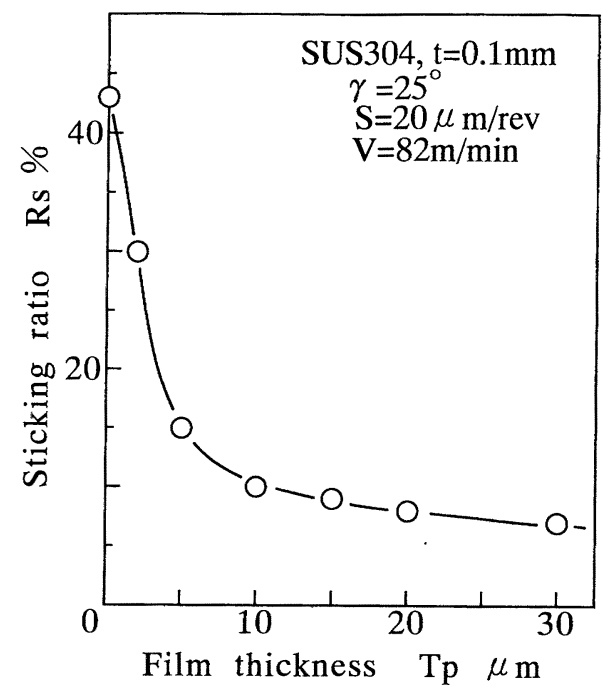

Fig. 9 Relation between film thickness and sticking ratio

する. 皮膜厚さを $15 \sim 20 \mu \mathrm{m}$ 程度とすると, さらに 薄板相互の溶着む低減し, 良好な絨維の得られるこ とが確認できた. 皮膜厚さを $30 \mu \mathrm{m}$ と厚くすると, 溶着率は $8 \%$ 以下と少ない值を示すが，軟質の PVAL 量が多くなるため切削中に薄板の変形が発 生しやすくなり，良好な繊維製造が困難となった。

また, 板厚 $t=0.03 \mathrm{~mm}$ の SUS304 材であ同様の 実験を行った結果, $20 \mu \mathrm{m}$ 程度の皮膜厚さでも板厚 に対する PVAL 量が多くなり, 切削中に薄板の変 形が生じ易くなった，緊密な積層状態が保持され， 連続的な繊維生成が可能となる PVAL 皮膜厚さは 板厚が小さくなるとより薄くする必要があると思わ れる。

\section{4 洗浄。巻取装置}

試作した洗浄・巻取装置を図10に示す，洗浄，巻 取工程は切削された金属繊維に付着したPVAL 皮 膜を洗浄除去し，巻き取るあのである．洗浄装置に は繊維の引取ロールが取り付けられ, 繊維生成速度 に一致した速度で洗浄槽内を移送, 洗浄される.さ らに, 洗浄槽は 2 槽方式とし PVAL ととあに切削 油等の污れむ洗浄できるようにした，洗浄槽へは污 濁, 温度低下を防ぐために, 約 $75^{\circ} \mathrm{C}$ の温水を $10 \ell /$ min で供給した. 洗浄後の繊維に残存する PVAL をソクスレー抽出器で測定したところ温水温度 $75^{\circ} \mathrm{C}$, 浸漬時間 $20 \mathrm{sec}$ で $97 \mathrm{Wt} \%$ の PVAL 皮膜が 除去されていることが確認された. さらに，洗浄時 


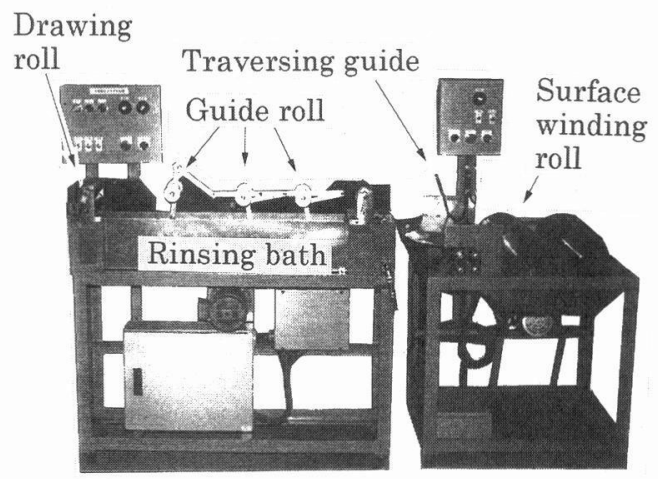

Fig. 10 Rinsing and winding equipment

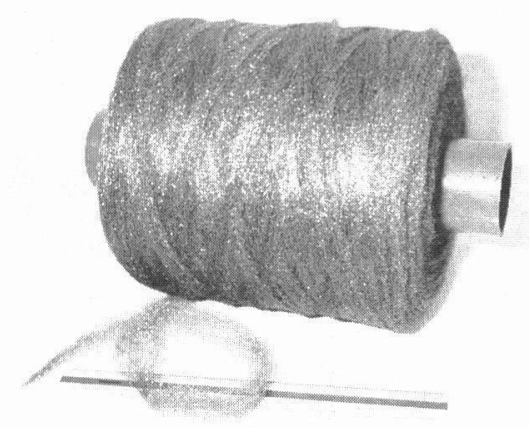

Fig. 11 Wound stainless steel fiber by hot water soluble resin coated coiled sheet shaving method

間の延長, 温水供給量の増加により残存 PVAL 量 の減少は可能になるものと思われる. 巻き取られた 金属繊維の外観を図11に示す。

\section{5 各種金属䋊維の製造}

次に，本法を用いて各材種の金属繊維製造実験を 行った. 実験の諸条件を表 2 に示す. 切削速度は材 種により $60 \sim 82 \mathrm{~m} / \mathrm{min}$ に変化させ, 送り量は $20 \mu \mathrm{m} / \mathrm{rev}$, すくい角は各材種で最む良好な繊維の 得られるすくい角とした。 切削工具はニッケル繊維 製造で SKH9 種, それ以外は超硬工具（K10）を用 い湿式切削とした. 得られた繊維の外観とその拡大 したものを図12に示す. PVAL を被覆しない通常の 切削では（a）に示すように各材種とも薄板相互の 溶着が多く, 帯状のカールした切りくずとなり, 繊 維としての形態を示さない. PVAL を被覆して切削 した場合には（b) に示すように, どの材種屯薄板相 互の溶着が防止され，均一な金属繊維が製造できる
Table 2 Experimental condition

\begin{tabular}{l|l}
\hline \hline Cutting tool & $\begin{array}{l}\text { Sintered carbide tool (K10) } \\
\text { High speed steel tool (SKH9) }\end{array}$ \\
\hline $\begin{array}{l}\text { Cutting } \\
\text { condition }\end{array}$ & $\begin{array}{l}\text { Rake angle } \quad \text { : } 25^{\circ} \sim 42^{\circ} \\
\text { Back clearance angle } \alpha: 10^{\circ} \\
\text { Approach angle } \phi: 2^{\circ} \\
\text { Cutting speed v: } 74 \sim 80 \mathrm{~m} / \mathrm{min} \\
\text { Feed rate S: 15 } \sim 20 \mu \mathrm{m} / \mathrm{rev} \\
\text { Width of cut W: } 10 \sim 20 \mathrm{~mm} \\
\text { Coolant Water soluble coolant }\end{array}$ \\
\hline Work & $\begin{array}{l}\text { Stainless steel (SUS304) } \\
\text { materials } \\
\text { Permalloy (PC) } \\
\text { Nickel (N1) } \\
\text { Titanium (TP) }\end{array}$ \\
\hline Sheet & $\mathrm{t}=0.03,0.05,0.1 \mathrm{~mm}$ \\
thickness &
\end{tabular}

ことが確認された．また，（c）はPVAL 被覆により 製造された繊維の外観を拡大したものである.

次に，得られた金属繊維の繊維径について検討を 行った。本方法で得られる金属繊維の断面の一例を 図13に示す. 各繊維の送り量に対する換算直径を図 14に, また, 図13に示した繊維厚さ増加比 Ri（実際 に得られた織維厚さ／工具の送り量）の変化を図 15 に示す. 繊維の換算直径は $t=0.03 \mathrm{~mm}$ の場合 $30 \sim 48 \mu \mathrm{m}, \quad t=0.05$ の場合, $35 \sim 62 \mu \mathrm{m}, \quad t=0.1$ $\mathrm{mm}$ の場合, 50 ～ $85 \mu \mathrm{m}$ の範囲となった. 繊維厚さ 増加比は材種による差はほとんど認められず, 送り 量が小さくなるに従って大きくなっている，これは 送り量 (切削厚さ) に対して工具刃先の丸みが相対 的に増加するため, 繊維生成時の実せん断角が減少 するためと思われる. また, 材種による繊維厚さ増 加比の差異が認められないことから, 当然材種によ る繊維径の差異む認められなかった。

また, これらの材種以外に, 銅, 黄銅, アルミニ ウム, ジルコニウム等の纎維製造を行い，いずれの 材種であ本方法が有効であることが確認された。 し かし，銅，黄銅の場合には，温水での洗浄の際，表 面酸化が生じた。これを防ぐためには皮膜を洗浄除 去した直後に乾燥させる工程をとる必要があると思 われる。

\section{3. 不織布製造装置}

\section{1 不織布製造法}

既存のカーディング法等の不織布製造法は工程が 


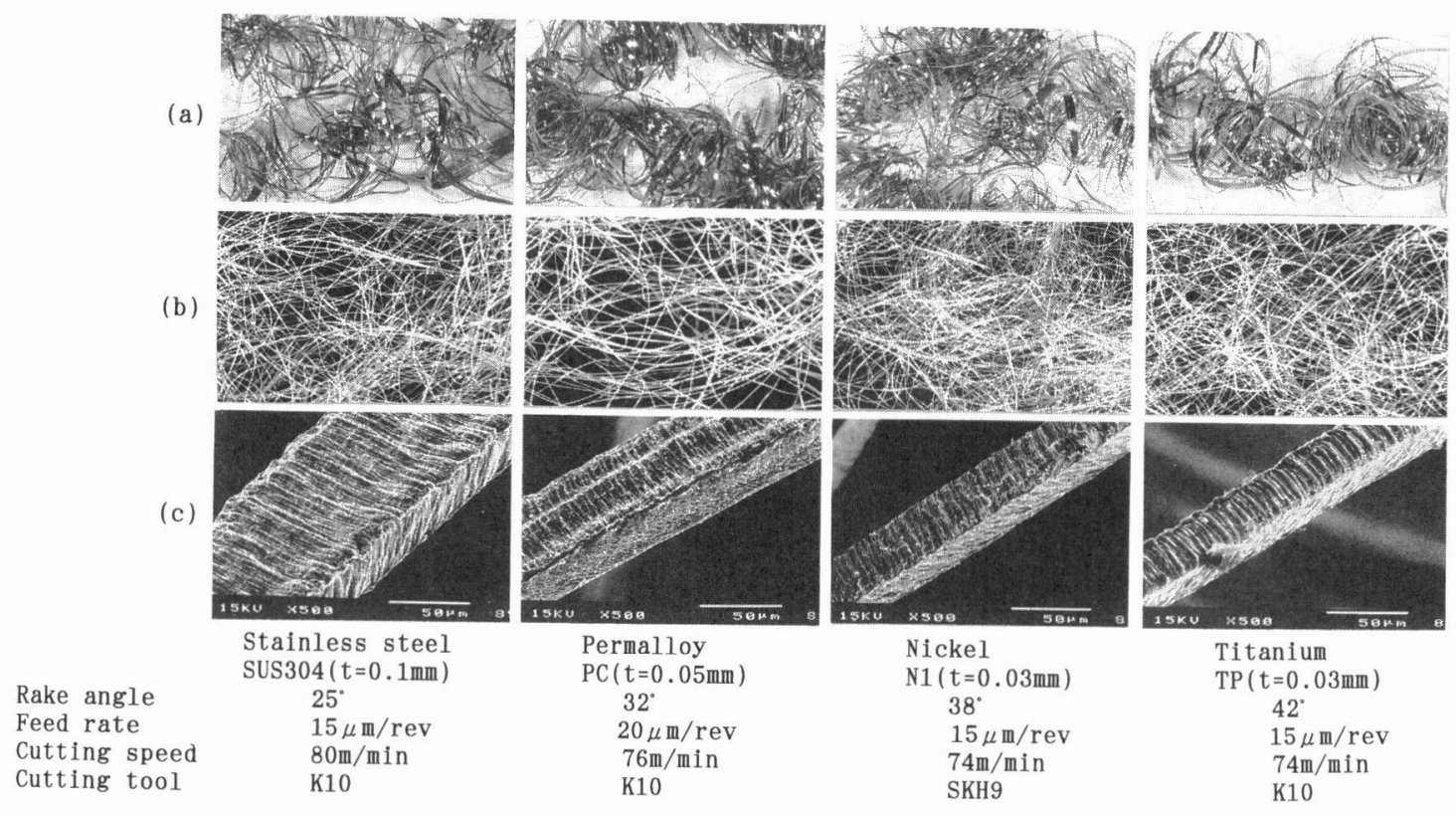

Fig. 12 General view and magnification of fibers produced by hot water soluble resin coated coiled sheet shaving method

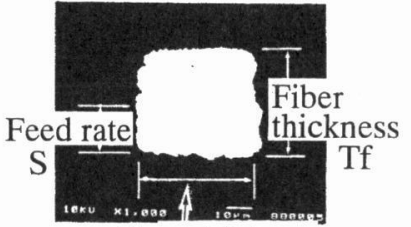

Sheet thickness

Increase ratio $\mathrm{Ri}=\frac{\mathrm{Tf}}{\mathrm{S}}$

Fig. 13 Fiber cross section

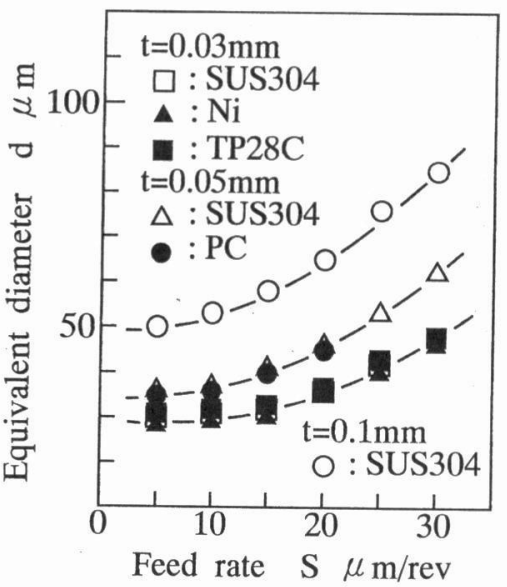

Fig. 14 Relation between feed rate and equivalent diameter

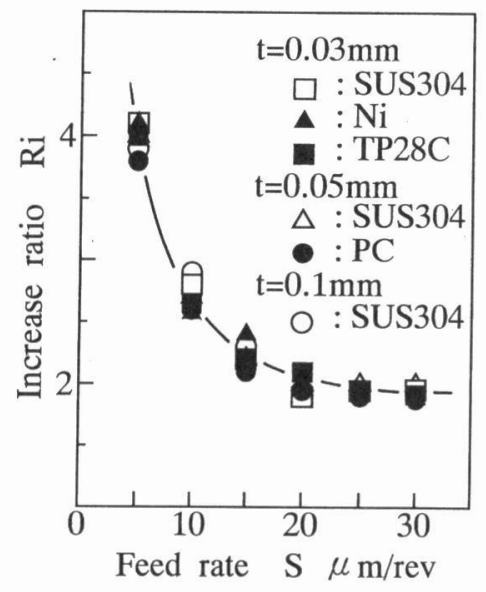

Fig. 15 Relation between feed rate and increase ratio

複雑で, 大規模な装置を必要とし,さらに，コイル 材切削で得られる金属瀻維は瀻維製造時の加工硬化 等により, 織維が折損しやすく, 従来法では大きな 曲げ加工を受けるため, 短繊維状あるいは粉末状と なりやすく不織布の製造が困難である。ここでは, コイル材切削法による金属繊維に適した不織布製造 法の検討を行った. 本方法で用いた不織布製造法の 原理を図16に示す．この方法は速度比の異なる供給 


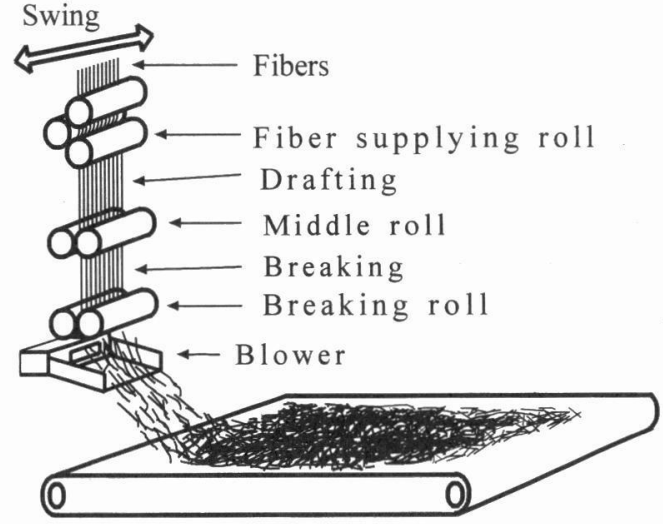

Fig. 16 Schematic illustration of web production method

ロールと中間ロールで綫維を部分的に切断し, さら に高速回転の切断ロールで完全に切断分離し, エア によりコンベア上に飛散させ, 無配向に積み重ね, 連続した不織布を製造するものである. 本装置では このように, 部分的な切断の後に, 高速回転ロール で完全な分離切断を行う 2 段階での切断方法を採用 している.これは, 1 段での切断工程でも, 速度比の 選択により, 䋐維切断は可能であるが, 切断された 繊維が充分に分離開繊せず，コンベヤ上に飛散する ため, 均一な分散が得られないため, 中間ロールに 対して大きな速度比で高速回転する切断ロールを用 いることによって, 良好な分離開緎が行われるよう にしたあのである。 また, 広幅の不織布の製造に対 応するため, この 2 工程切断装置を幅方向に摇動さ せる構造とした。このとき両端部での分散繊維量の 低下を防ぎ, 幅方向に密度の均一な不織布を得るた めに, 摇動速度を摇動中央部に対して両端部で变速 可能にした.

\section{2 不織布製造装置}

製作した不織布製造装置の外観を図17に示す．回 転ロール部（繊維供給ロール, 中間ロール, 切断口 ール）を幅方向に摇動させることで幅広でしかむ均 一な不織布が製造可能な構造とした。ここでは, 湯 溶性樹脂被覆コイル材切削法で得られた換算直径 30, $60,90 \mu \mathrm{m}$ のステンレス鋼繊維を用い不織布製 造実験を試みた。

まず, はじめに, 良好に切断, 分散させるための 各ロールの速度比の検討を行った. 各ロールの速度 比は $1: 2 \sim 3: 10 \sim 20$ の範囲が最む均一に切断, 分

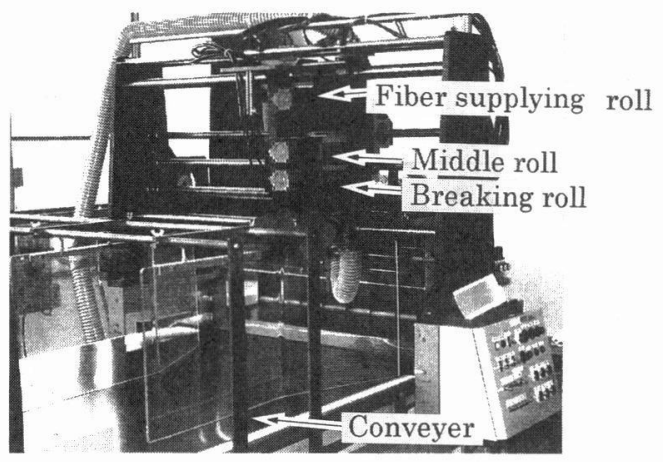

Fig. 17 Web production machine

散が可能であった。供給ロールと中間ロールの速度 比が $1: 1.5$ 以下と小さい場合には, 切断ロールの 速度比を $3: 10 \sim 3: 20$ の間で変化させても, 切断 された繊維と切断されない長繊維の混合したものと なり, 均一に分散させることが困難である。逆に, 速度比が $1: 4$ と大きくなると供給ロールと中間口 ール間で繊維が完全分断し, これはそのまま切断口 ールを通過するため開㵶せず均一性が極端に悪くな った.

次の切断絨維長さの測定を行った。ここでは, 良 好に切断, 分散できる条件である $1: 3: 15$ の各口 ール速度比で中間ロールと切断ロールの中心距離を 50〜150 mm に変化させ, 切断された緘維長さの測 定を行った。 その結果を図18に示す. 繊維平均長さ は繊維径の違いによってはほとんど変化せず，中間

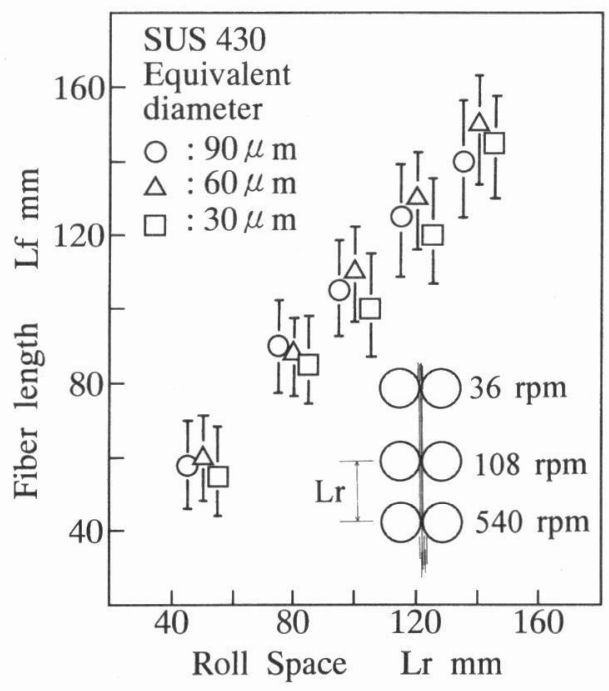

Fig. 18 Fiber length by space between middle roll and breaking roll 


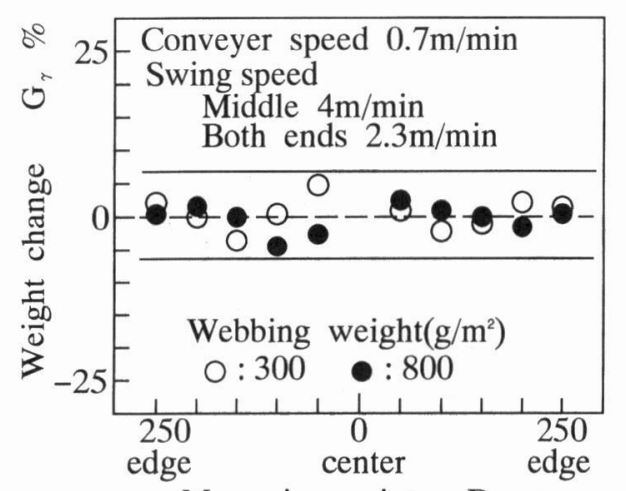

Measuring point Dc $\mathrm{mm}$

Fig. 19 Change of webbing weight

ロールと切断ロールの中心距離にほぼ対応すること が確認された。 また, 切断長さが大きくなるに従っ て，纎維長さのばらつきの絶対値は大きくなるもの の, ばらつきの切断長さに対する割合はむしろ減少 することが確認された.

さらに，実際の不織布の製造実験を行った，瀻維

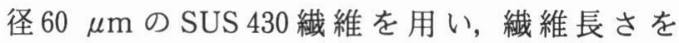
$100 \mathrm{~mm}$, 不織布の幅を $500 \mathrm{~mm}$ とした. また, 目付 け量が 300 および $800 \mathrm{~g} / \mathrm{m}^{2}$ となるようにコンべヤ 速度を $0.7 \mathrm{~m} / \mathrm{min}$, 繊維供給量を $107 \mathrm{~g} / \mathrm{min}$, $285 \mathrm{~g} / \mathrm{min}$ とした. 摇動速度はコンベヤ移送方向へ の均一分散および両端部での均一分散を考慮して, 中央部で $4 \mathrm{~m} / \mathrm{min}$, 両端部で $2.3 \mathrm{~m} / \mathrm{min}$ とした. 目付量の測定は $500 \times 500 \mathrm{~mm}$ の大きさの不織布を $50 \times 50 \mathrm{~mm}$ に分割し, それぞれの重量測定を行い 目付量へ換算した。 目付量のばらつきの測定結果を 図19に示す．本装置での目付け量のばらつきは土 $5 \%$ 以内であり, 均一な不織布が得られることが確 認された。 また, 織維径 $90 \mu \mathrm{m}, 30 \mu \mathrm{m}$ についても 同様の実験を行った. 繊維径 $90 \mu \mathrm{m}$ の場合にはほぼ 同じ結果が得られたが, 繊維径 $30 \mu \mathrm{m}$ と細くなると 切断長さ $100 \mathrm{~mm}$ では分散が悪くなり, 目付量のば らつきが大きくなった. しかし, 繊維長さを $50 \mathrm{~mm}$

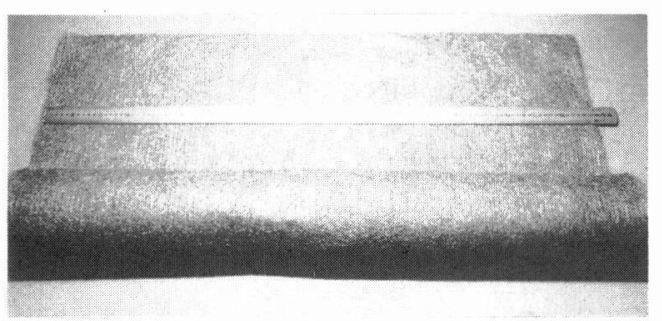

Fig. 20 Appearance of web produced by developed webbing machine

と短くすると均一分散が可能になり, 同様の結果が 得られた. 図20に本装置で得られた換算直径 60 $\mu \mathrm{m}$, 目付量 $800 \mathrm{~g} / \mathrm{m}^{2}$, 幅 $1 \mathrm{~m}$ の SUS430 のステン レス鋼繊維の不織布の外観を示す.

\section{4. 結 言}

コイル材切削法による金属繊維を実用化するため に, 湯溶性樹脂被覆装置, 金属繊維製造装置および 洗浄, 巻取装置, さらに二次加工装置としての不織 布製造装置を開発し, 基本的な機能の確認実験を行 った。 また, 各種金属織維の製造, 不織布の製造実 験を行った。 その結果, 本製造装置は実生産に十分 対応できる能力を持っていること, 不織布製造装置 は本方法による金属瀻維に適していること, また, 本方法および製造装置で多材種の金属繊維が製造で きることが確認された。

\section{文 献}

1）渡辺輝男；ステンレス鋼極細線の引き拔き，塑性之加工， 9, 211, 692 (1978)

2）中川威雄, 柳沢章, 鈴木清; 金属繊維の製造と応用, 紻維 と工業, 39, 4, 121 (1983)

3）中川威雄, 鈴木清, 植松啓太郎, 小山浩幸 : びびり振動切 削による金属短織維の製造, 精密機械, 17，11，85（1981）

4）兼子正生, 柳沢章, 中川威雄 : 金属織維製造のための薄板 コイル材切削における紻維溶着現象の検討, 精密工学会 誌, 61, 5, 692 (1995)

5）兼子正生, 柳沢章, 中川威雄 : 湯溶性樹脂被覆コイル材切 削法によるステンレス鋼織維の製造, 精密工学会誌, 62, 1, 110 (1996) 